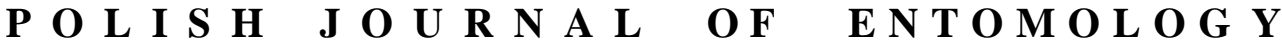

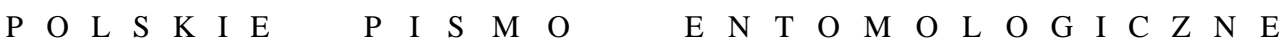

VOL. 84: 9-20

Lublin

30 April 2015

DOI: $10.1515 /$ pjen-2015-0002

\section{Current distribution of the Rosalia longicorn Rosalia alpina (LINNAEUS, 1758) (Coleoptera: Cerambycidae) in Poland}

\author{
JAKUB MichaLCEWICZ ${ }^{1}$, MichaŁ CiACH $^{2}$ \\ ${ }^{1}$ Department of Forest Protection, Entomology and Forest Climatology, Institute of Forest \\ Ecosystem Protection, Faculty of Forestry, University of Agriculture, Al. 29 Listopada 46, \\ 31-425 Kraków, Poland, e-mail: j.michalcewicz@ur.krakow.pl \\ ${ }^{2}$ Department of Forest Biodiversity, Institute of Forest Ecology and Silviculture, Faculty of \\ Forestry, University of Agriculture, Al. 29 Listopada 46, 31-425 Kraków, Poland, \\ e-mail: michal.ciach@ur.krakow.pl
}

\begin{abstract}
The former range of the Rosalia longicorn Rosalia alpina in Poland probably overlapped with the range of the European beech Fagus sylvatica. In the $20^{\text {th }}$ century, the species was recorded in the following parts of Poland: the Carpathians (almost the entire range), the Świętokrzyskie Mountains, the Roztocze Upland, Lower Silesia, and the northern and northwestern parts of the country. Although the Rosalia longicorn appears to have regressed in the countries of central Europe, the current population trend of this species in Poland is not known. This study presents data on the distribution of the Rosalia longicorn in Poland in 2000-2013 and defines its current distribution and range. A total of 210 sites of the Rosalia longicorn were identified, situated in 42 UTM squares $(10 \times 10 \mathrm{~km})$. The total area of the species' occurrence (maximum convex polygon) was $3334 \mathrm{~km}^{2}$ and the effectively used area was $1877 \mathrm{~km}^{2}$. The Rosalia longicorn has withdrawn from most of its former sites in Poland and at present occurs only in parts of the Carpathians. Its continuous distribution range comprises the Bieszczady Zachodnie and Beskid Niski Mountains. Scattered and less abundant sites occur in the Beskid Sądecki, Pieniny Mountains and Sanok-Turka Mountains. At present, therefore, the species' range of occurrence in Poland is significantly smaller than that recorded in the $20^{\text {th }}$ century. The median nearest neighbour distance between sites was $1023 \mathrm{~m}$ (mean $=1640 \mathrm{~m} \pm 1702 \mathrm{SD}$, range 502-10870 $\mathrm{m}$ ). Those situated on the peripheries of the range are thinly scattered, and the distance between them is probably too large to allow free movement of the species. This can disrupt the current range and lead to the formation of isolated sites (islands) along its peripheries, from which the Rosalia longicorn may gradually disappear. Such a development could cause its total extinction. The current distribution of the Rosalia longicorn in the Carpathians suggests that certain detrimental processes are taking place in the population, demonstrating that the species' extinction in Poland is ongoing.
\end{abstract}

KEY WORDS: Rosalia alpina, endangered species, distribution, range, isolation, Carpathians, Poland. 


\section{INTRODUCTION}

The endangered Rosalia longicorn Rosalia alpina (LINNAEUs, 1758) is a species with an Euro-Caucasian distribution (STARZYK 1992, 2004, EHNSTRÖM 2007, SHAPOVALOV 2012, IUCN 2014). It occurs in central and southern Europe - from Portugal and Spain, through France, Italy (along with Corsica, Sardinia and Sicily), the countries of central Europe and the Balkans, to the Ural Mountains, the Crimea, the Caucasus, Transcaucasia, north-eastern Turkey and north-western Iran. The southern limit of the species' range is represented by sites in North Africa (the Atlas Mountains) and the Middle East (IUCN 2014). The species reaches the northern limit of its range in central Europe, with some isolated sites in Sweden and Denmark (STARZYK 1992, 2004, EHNSTRÖM 2007). However, the current distribution of the Rosalia longicorn in Europe is highly fragmented and there are only a few isolated areas of occurrence in central Europe (BINNER \& BUSSLER 2006).

In central Europe, the Rosalia longicorn originally inhabited beech forests. However, the species has recently been observed to spread into lowland beech-free forest stands (ČÍžEK et al. 2009). The Rosalia longicorn is a polyphagous species, although in central Europe it is mainly associated with the European beech Fagus sylvatica LinNAEUs, 1753 (ŠVÁCHA \& DANILEVSKY 1988, BURAKOWSKI et al. 1990, SAMA 2002). In the past, the species probably occurred within the entire Polish range of the European beech: in the $20^{\text {th }}$ century it was recorded in Lower Silesia, in the Beskid Śląski and Beskid Wysoki Mountains, the Tatra Mountains, the Świętokrzyskie Mountains, the Roztocze Upland, as well as in northern and north-western Poland. From the first information on the species' occurrence in Poland in 1801 to the end of the $20^{\text {th }}$ century, a total of ca 60 Rosalia longicorn sites (i.e. 10x10 km squares) were found in the country (see STARZYK 2004).

The body of knowledge on the Rosalia longicorn's distribution in Poland is based largely on historical information. As the currently available data come from a relatively long period (200 years), some of the sites reported (STARZYK 2004) had probably become historical by the time the data were published. At present, no later information on the occurrence of this species in Poland is available. The aim of this paper was therefore to determine the current distribution and limits of the Rosalia longicorn's range in Poland. At the same time, this information will help to establish the species' current range in central Europe.

\section{MATERIAL AND METHODS}

The distribution of the Rosalia longicorn in Poland was determined on the basis of available data from 2000-2013, both published (BODZIARCZYK \& MichALCEWICZ 2000, MichalCEWICZ \& BoDZIARCZYK 2001, ZYGarowiCZ 2003, CiACH et al. 2007, 
Michalcewicz \& BodziarczyK 2008, Ciach \& Michalcewicz 2009, MichalcewicZ et al. 2011a, 2011b, MichalCEWICZ \& CiACH 2012a, 2012b, 2012c, MichalCEWICZ et al. 2013, Ciach \& Michalcewicz 2014, MichalcewicZ \& ŁuszCZaK 2014) and unpublished, including our original data. The study used the data gathered in 2007 as part of the nationwide species survey in Poland, made available by the General Directorate of State Forests (74 records), and data from the Regional Environmental Protection Directorates were included. The staff of State Forests and National Parks were contacted, as well as entomologists and other persons in possession of information on the species.

Geographic coordinates were determined for every record of the Rosalia longicorn. Altogether, we obtained 540 records of the species in 2000-2013. Records with an inaccurate location or those resulting from the artificial transfer of the species with transported timber (sawmill material, firewood) were excluded from the total number of records. As a result, our analysis examined 514 records. In the next step, records relating to the same locality but coming from different years or different sources were combined. Records separated by up to $100 \mathrm{~m}$ from each other were defined as being from one locality. This resulted in the data on 344 localities of the species. Localities located within a distance of up to $500 \mathrm{~m}$ were taken to represent the same site. The adopted distance takes into account the probability of Rosalia longicorn movements over a distance of $500 \mathrm{~m}$ (DRAG et al. 2011) and takes the administrative and spatial diversification of forests in the Carpathians (forest units with different species composition and different age) into consideration.

The occupancy of UTM squares was determined based on the records of species within a given square. A square was defined as occupied if the species was recorded at least once during the period under consideration. Based on UTM square occupancy, the current range of the species is comparable with the results obtained at the end of the $20^{\text {th }}$ century, where ca 10x10 km squares were applied in the work on the red data book (STARZYK 2004). Despite the fact that the squares from the UTM grid and those from the red data book grid do not overlap, they have a similar shape and area. The area occupied by the population $\left(\mathrm{km}^{2}\right)$ was calculated using two methods: (1) as the total area, which is a maximum convex polygon based on the most extreme localities, and (2) as the effectively used area, which was defined as a buffer zone of $3000 \mathrm{~m}$ around each site. The value of $3000 \mathrm{~m}$, assumed to be the potential distance of adult Rosalia longicorns' regular movements, was based on the predicted probability of the species' movements (DRAG et al. 2011). Although these authors suggested that the maximum potential distance of adult Rosalia longicorn movements can theoretically be as much as several kilometres, the probability of such long distances being covered is extremely low. The polygons obtained with these two approaches were fitted within the national borders of Poland. The nearest neighbour distance between the sites was 


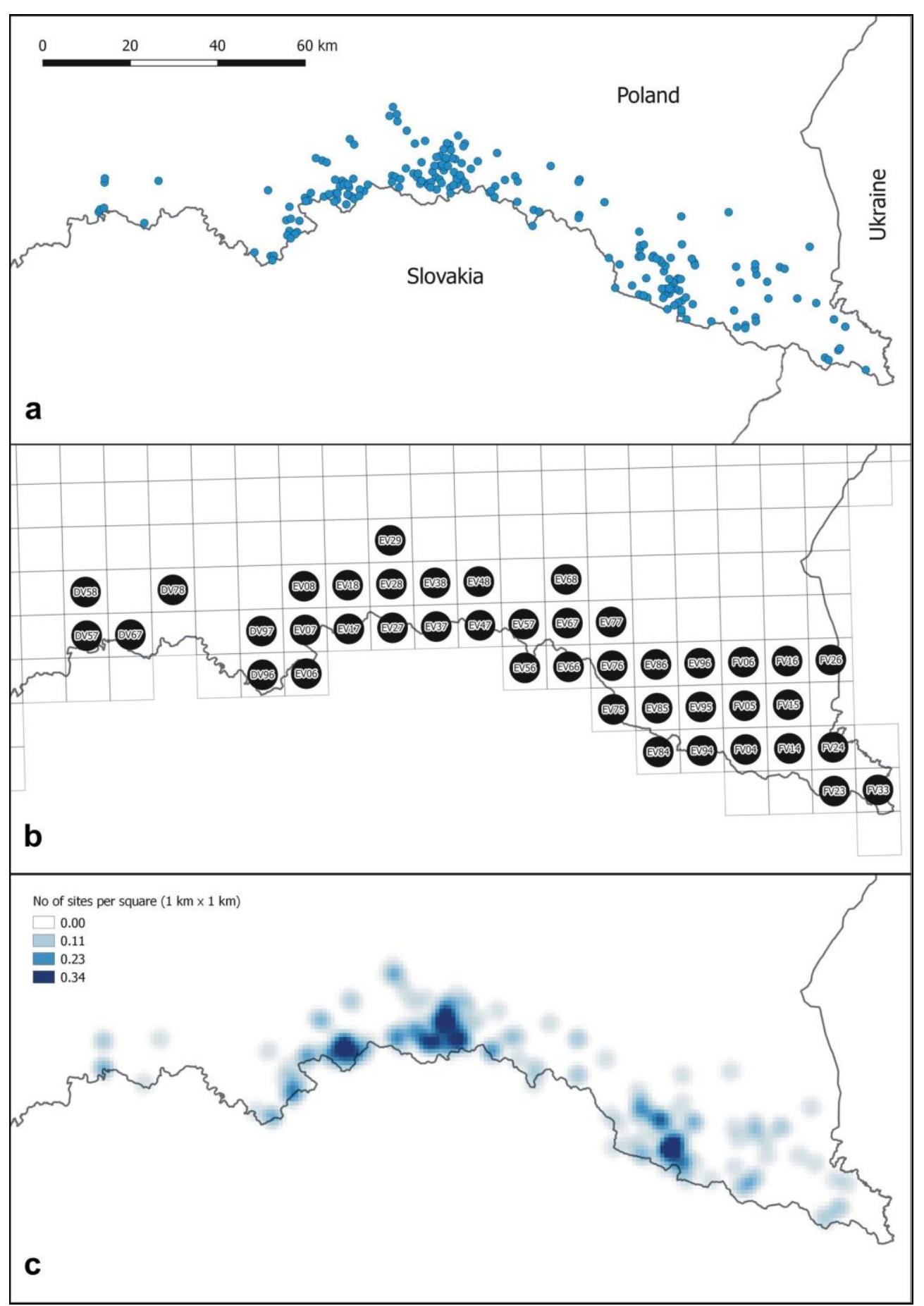


calculated as the distance between the centres of the two nearest sites. Kernel density estimation was used to create a density raster of the input point vector layer with the sites. The density of the sites was calculated on the basis of their number in the $1 \times 1 \mathrm{~km}$ resolution grid and the radius of $3000 \mathrm{~m}$ around each site. The density raster enables site clustering tobe identified. Spatial analyses were done with Quantum GIS software (QGIS 2014). The names of the physiographic units follow KONDRACKI (2000). For the analysis of the current distribution of the Rosalia longicorn in the Carpathians, data from the Czech Republic and Slovakia were also used (DRAG et al. 2012, ČERNECKÝ et al. 2014, ŠOPSR 2014).

\section{RESULTS}

In 2000-2013, 210 Rosalia longicorn sites were found in Poland: these sites are situated only in the Carpathians (Fig. 1). The main area of the species' occurrence includes the Beskid Niski and Bieszczady Zachodnie Mountains, and there were a smaller number of sites in the Beskid Sądecki, Pieniny and Sanok-Turka Mountains. The Rosalia longicorn was recorded in 42 UTM squares. The northern limit of the species range was continuous only in the central part of the Beskid Niski Mountains; otherwise it consisted of scattered sites. The distribution of the sites showed there to be a continuous range in two areas of the Carpathians: the central and western parts of the Beskid Niski Mountains and at the western end of the Bieszczady Zachodnie Mountains. At the same time, two disjunctions in the species range were found: on the border between the Bieszczady Zachodnie and Beskid Niski Mountains, and also in the Beskid Sądecki Mountains. The sites in the Pieniny and Sanok-Turka Mountains, as well as in the western part of the Beskid Sądecki Mountains are isolated.

The total area of the species range was $3334 \mathrm{~km}^{2}$, while the effectively used area was $1877 \mathrm{~km}^{2}$. The mean and median nearest neighbour distances between the sites were 1640 $\mathrm{m}$ ( $\pm 1702 \mathrm{SD}$ ) and $1023 \mathrm{~m}$ (quartile range 731-1714 m) respectively (range 502-10870 m). As many as $70 \%$ and $87 \%(\mathrm{~N}=210)$ of the sites have a nearest neighbour distance of less than $1500 \mathrm{~m}$ and $3000 \mathrm{~m}$ respectively. In total, $13 \%$ of the sites were situated further away than $3000 \mathrm{~m}$ from the nearest neighbour site (Fig. 2).

Fig. 1. Distribution of Rosalia longicorn Rosalia alpina in Poland in 2000-2013: $\mathrm{a}$ - distribution of sites, $\mathrm{b}$ - occupied UTM squares, $\mathrm{c}$ - kernel density estimation. 


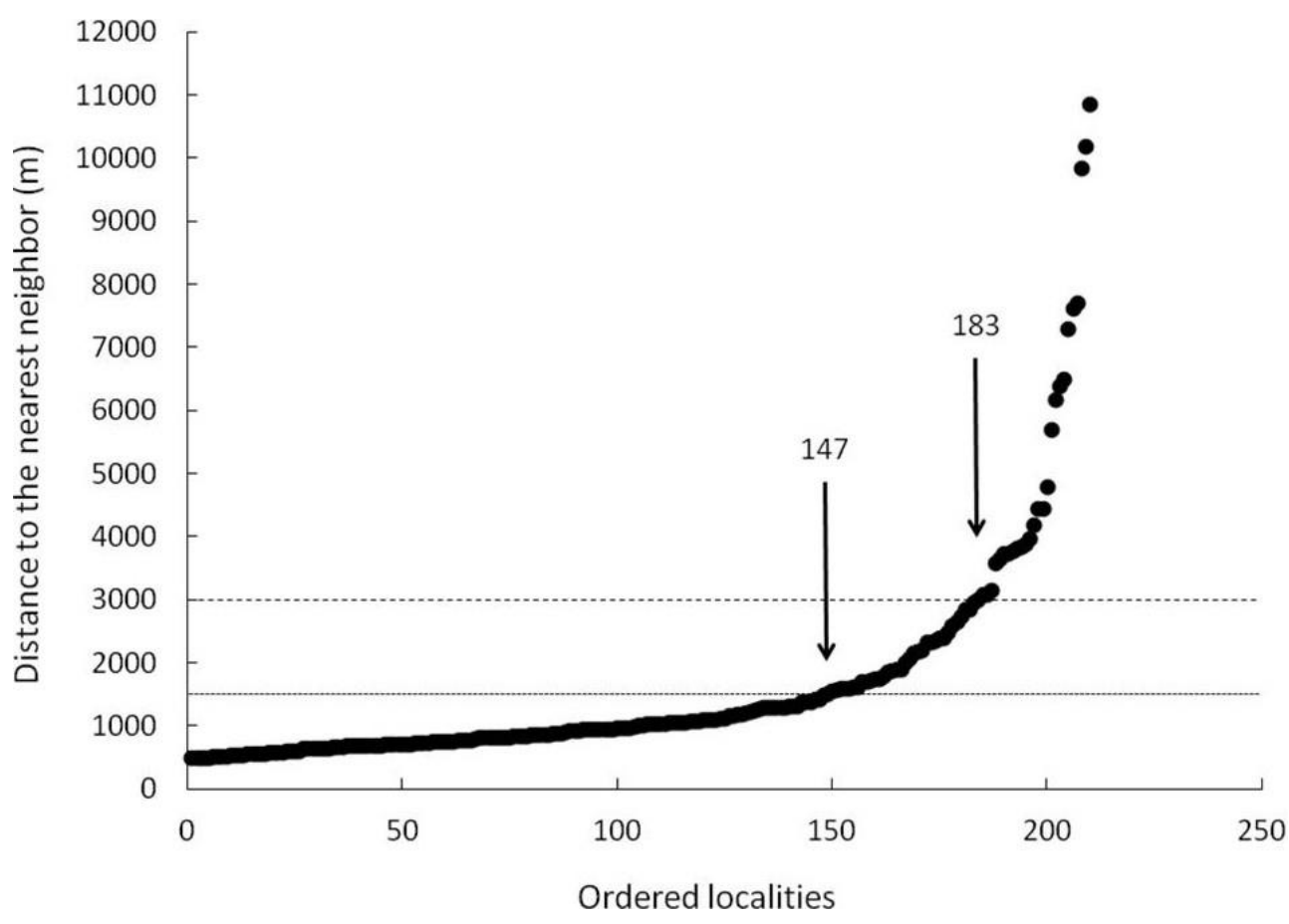

Fig. 2. Distribution of the nearest neighbour distances (NND) between Rosalia longicorn Rosalia alpina sites $(\mathrm{N}=210)$ in Poland in 2000-2013 (147 - number of sites with NND $<1500 \mathrm{~m}, 183$ - number of sites with NND $<3000 \mathrm{~m}$ ).

\section{DISCUSSION}

The results of this study indicate that changes have taken place in the range of the Rosalia longicorn in Poland: the species has abandoned most of its former sites and at present occurs only in parts of the Carpathians. The results are consistent with the adverse changes in the population observed within the entire range of the species in central Europe. Comparison of the historical and current range of the Rosalia longicorn in Europe shows that the species has withdrawn from localities in the northern part of its range. The former northern limit of the Rosalia longicorn was wedge-shaped and ended with isolated sites in Sweden and Denmark (see STARZYK 1992). This beetle occurred in southern Halland, in Skåne, Blekinge and eastern Småland in the $18^{\text {th }}$ and $19^{\text {th }}$ centuries; the last time the species was seen in these regions was in the 1920s (EHNSTRÖM 2007). In most of Germany, the species has become extinct; a small population has survived only in the southern part of the country (BENSE 2002). The distribution in Austria, Switzerland and Slovakia is less fragmented in some parts of the Alps and Carpathians (SLÁMA 1998, GEPP 2002, DUELLI 
\& WeRMELINGER 2005, JENDEK \& JENDEK 2006, LACHAT et al. 2013). Although many populations existed in the Czech Republic at the beginning of the $20^{\text {th }}$ century, only a few populations survived till the end of that century (SLÁMA 1998, DRAG et al. 2012). The results of the present study and the literature data indicate that the northern limit of the species has moved southwards, so that at present it runs through southern Germany, along the foot of the Alps, in the northern part of the Czech Republic, where it is not found beyond the Sudeten Mountains, and in southern Poland, in the Carpathians.

Changes in the course of the northern limit of the Rosalia longicorn's range are due mainly to the degradation and loss of its habitats as a result of modern forest management practices. The fact that imagines fly to wood stacks has probably contributed to the species' extinction. The beech timber stacked at depots acts as an ecological trap (ADAMSKI et al. 2013). Additionally, within the isolated population of limited spatial range and density, the role of stochastic processes responsible for the "Allee effect" (STEPHENS et al. 1999) increases. One possible mechanism of the role of stochasticity in reducing the population of the Rosalia longicorn was proposed by ADAMSKI et al. (2013).

The distribution of the Rosalia longicorn in the Carpathians should be analysed together with data from the Czech Republic and Slovakia. In the Czech Republic, the species has become extinct at most of its known sites: at present its distribution is limited to four scattered regions (DRAG et al. 2012). The sites in eastern Moravia are linked to the species' range in Slovakia, but the sites in Bohemia are isolated. In Slovakia, the species has a high prevalence, but its range is not continuous (ČERNECKÝ et al. 2014, ŠOPSR 2014). However, the current data from Slovakia and Poland indicate the existence of a disjunction in the Beskid Sądecki Mountains. Consequently, the sites in the Pieniny Mountains, the Sanok-Turka Mountains, and the western part of the Beskid Sądecki Mountains are isolated. The disjunction between the Bieszczady Zachodnie and Beskid Niski Mountains exists only on the Polish side of the border; the connectivity of the population can be maintained only through the sites situated on the Slovakian side. At present, some of the Rosalia longicorn sites in the Polish Carpathians are probably isolated enough for there to be no contact between them (see Figs 1,2). The lack of recolonisation opportunities may result in a permanent reduction in range, despite the presence of suitable habitats. The distances between some of the Rosalia longicorn's sites at the limits of its current range may not allow free movements of imagines. As a consequence, islands (isolated sites) may slowly develop on the peripheries of its range. Contraction of the Rosalia longicorn's continuous range and its disappearance from isolated sites may eventually lead to its extinction. The sites in the Pieniny Mountains, the Sanok-Turka Mountains, and the western Beskid Sądecki Mountains appear to be the most vulnerable. It should be noted, however, that the maximum dispersal abilities of the imagines are unknown and could be higher than the distance used in our study. As discussed in DRAG et al. (2011), the mark- 
recapture method applied in their study underestimates the potential for long-distance dispersal.

The body of knowledge relating to the distribution of many insect species has increased in recent years, and this is associated with the establishment of the Natura 2000 network, and consequently with the censusing and monitoring of species, education on insect conservation, and a significant acceleration in the information flow. The Natura 2000 Programme has contributed significantly to a better understanding of the distribution, biology, ecological requirements and threats to the beetles listed in the annex to the Habitats Directive (GUTOWSKI \& PRZEWOŹNY 2013). Nevertheless, studies of changes in the Rosalia longicorn's population are difficult since no regular monitoring has been conducted to date. Some endangered species may indeed be displaying an adverse trend in their abundance and progressive reduction in their range despite the increasing number of observations. Starting with the first report on the occurrence of the Rosalia longicorn in Poland in 1801, ca 60 sites of the species were identified in Poland by the end of the $20^{\text {th }}$ century ( 10x10 km squares) (STARZYK 2004). Recent estimates indicate the existence of 30-40 sites of the Rosalia longicorn, limited to the Carpathians (GUTOWSKI \& PRZEWOŹNY 2013). The results of this study support these estimates and indicate that the species occurs in only 42 UTM squares. Comparison of the occupied UTM squares and the squares from the red data book grid (STARZYK 2004) indicates that the species has disappeared from nearly $30 \%$ of the latter. It should be emphasised that the number of Rosalia longicorn sites recorded in 2000-2013 in the course of this study is the result of the methodology adopted, i.e. the introduction of a site definition (localities situated more than $500 \mathrm{~m}$ apart were defined as different sites), and probably from the better identification of the species. For this reason, the results of our study should not be interpreted as a spectacular increase in the number of sites compared to the hitherto reported number (see GUTOWSKI \& PRZEWOŹNY 2013).

Changes in the forest habitat, such as denser tree canopies and increasing shade within a forest stand, may also be making an important contribution to the Rosalia longicorn's disappearance. These changes are associated with the implementation of modern forestry methods (cultivation of trees with desired characteristics, attention to sanitary conditions, increased canopy cover, elimination of livestock grazing) and natural succession. The deterioration of light conditions in forests may further exacerbate population drainage through the increased movements of imagines towards beech timber stacked in spots receiving a high level of insolation. The adverse thermal conditions prevailing in dense forests, despite the presence of dead wood, are likely to be the cause of the phenomenon lately observed in Poland, whereby these beetles use habitats located outside the forest (roadside trees and woodlots in pasturelands) and also their transfer to a different host plant (Michalcewicz \& Ciach 2012c, Ciach \& Michalcewicz 2014). The fact that the 
breeding material requires high insolation for development is reflected in the species' preference for open forests, even in the climate of the Italian Peninsula (RUSSO et al. 2011).

Implementation of conservation measures in relation to the Rosalia longicorn in the Carpathians is a prerequisite for the survival of its populations. The key issue in the protection of this longhorn beetle consists in the preservation/restoration of dead European beech wood, while eliminating the population drainage caused by movements of imagines towards stacks of beech timber. Only strict adherence to recommendations regarding the protection of this saproxylic beetle (see MicHALCEWICZ \& CIACH 2012b) can prevent further reduction of its range and the decline of its population. Monitoring of the Rosalia longicorn population should begin with gathering further knowledge about its distribution.

In conclusion, the Rosalia longicorn has abandoned most of its former sites in Poland and at present occurs only in the south-easternmost part of the country. The continuous range of the species comprises the eastern part of the Carpathians with scattered and less abundant sites in western part. The perforation of the current range and the gradual development of isolated sites along its peripheries is the most probable scenario, the consequence of which may be the gradual extinction of the species in Poland.

\section{Acknowledgements}

The authors wish to thank everyone who provided information on the occurrence of the Rosalia longicorn in Poland in 2000-2013: K. ADAMCZYK, P. ADAMSKI, A. ANDRZEJCZAKWilk, M. BarczyK, T. BartKo, B. Bącal, L. Bekier, K. BelniaK, K. Biskupska,

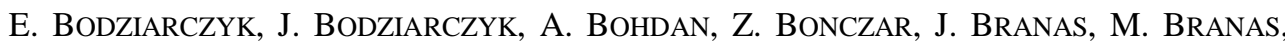
M. BroźNY, H. Brustel, M. BuJoczeK, S. BuKowieC, K. Bul, J. BurSZCZAN, G. CierLIK, J. Cieśla, A. Czaban, B. Czader, P. Czerniak, E. CZuchta, S. Czyżowicz, Z. DaszKiewicz, L. Dąbrowski, A. Derwich, I. DymińsKa, Ł. DZiUban, A. FlorCZAK, H. Frycz, M. Frycz, T. Furs, A. Gatka, L. Gęborys, P. Gracoń, A. Graboś, P. GRodziŃSKI, A. GRUSZKA, M. Hel, M. Holly, A. ILEK, D. JAKUBOWSKI, R. JARZĘBAK, M. JuRASZ, T. JuRKIEWICZ, P. Karaś, M. KarP, A. Kalemba, M. KŁAPACZ, J. KorZENIAK, K. KoszyK, M. KoszyK, R. KośCielniaK, A. KowalczyK, M. KozŁowski, K. KruK, M. Krzyżański, W. Kuchta, K. KunUlak, P. KuRek, L. Kusiak, R. Laskowski, A. Lasoń, A. Luks, A. ŁabęDzki, M. Łuszczak, D. Majkowska, A. Melke, Ł. MichalaK, G. Michalcewicz, W. Michalcewicz, J. Miszczyszyn, J. Niemiec, M. NowaK, W. Ochal, H. OKarma, T. Olbrycht, T. Olech, W. PiaszcZyK, W. Plata, D. PrzybyŁa, Ł. PrzybyŁowicz, P. Rębisz, R. Rossa, P. Różowicz, M. Scelina, E. SIEDLARCZYK, D. SObIESIAK, J. STARZYK, A. SUROWIECKI, M. STYLIŃSKI, J. SZAFARSKA,

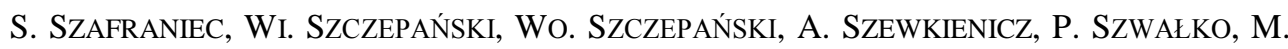
ŚWIDER, W. TABIŚ, D. TARNAWSKI, A. TASZAKOWSKI, K. TASZAKOWSKI, T. TrochimiUK, 
E. Tutak, K. Urban, A. Wach, M. Welnicki, J. WidelKa, A. Wiercińska, H. Wilk, J. Wilk-DziUban, Z. WitKowski, T. Wojas, A. Woźniak, R. ZAMORsKi, A. ZATOR, B. ZIOMEK, U. ZIOMEK, J. ZYGAROWICZ. We also acknowledge the General Directorate of State Forests and the Regional Environmental Protection Directorate in Kraków for provision of their data. We also thank Lukas Č́̇̌žEK and the anonymous reviewers for providing valuable comments on this paper.

\section{REFERENCES}

Adamski P., Holly M., Michalcewicz J., Witkowski Z. 2013. Decline of Rosalia longicorn Rosalia alpina (L.) (Coleoptera: Cerambycidae) in Poland - selected mechanisms of the process. [in:] W. ZĄBECKI (ed.). The role and contribution of insects in the functioning of forest ecosystems. Wydawnictwo Uniwersytetu Rolniczego w Krakowie, Kraków: 185-200. [In Polish]

BENSE U. 2002. Schutzmaßnahmen für den Alpenbock (Rosalia alpina) im Bereich der Schwäbischen Alb. DgaaE Nachrichten 16(2): 57-58.

BINNER V., BusSLER H. 2006. Erfassung und Bewertung von Alpenbock-Vorkommen. Naturschutz und Landschaftsplanung 38(12): 378-382.

Bodziarczyk J., Michalcewicz J. 2000. A new site of Rosalia alpina (L.) (Coleoptera, Cerambycidae) in the Radziejowa Range (Beskid Sądecki Mountains, Western Carpathians). Chrońmy Przyrodę Ojczystą 56(6): 126-129. [in Polish]

Burakowski B., Mroczkowski M., Stefańska J. 1990. Catalogue of Polish Fauna XXIII, 15. Beetles - Coleoptera. Cerambycidae and Bruchidae. PWN, Warszawa. [in Polish]

ČERnecký J., GalvánKová J., PovažAn R., SAXA A., ŠEFFer J., ŠEFFEROVÁ V., LASÁk R., JanÁk M. 2014. Conservation status of habitats and species of Community interest in the period of 2007 2012 in the Slovak Republic. State nature conservancy of the Slovak Republic, Banska Bystrica.

CiACH M., MichalCEWicz J. 2009. Egg morphology of Rosalia alpina (LinnaEus, 1758) (Coleoptera: Cerambycidae) from southern Poland. Entomological News 120(1): 61-64.

Ciach M., Michalcewicz J. 2014. Pastureland copses as habitats for a primeval forest relict: a unique location of the Rosalia Longicorn Rosalia alpina (L.) (Coleoptera: Cerambycidae) in the Polish Carpathians. Polish Journal of Entomology 83(1): 70-77.

Ciach M., Michalcewicz J., Fluda M. 2007. The first report on development of Rosalia alpina (Linnaeus, 1758) (Coleoptera: Cerambycidae) in wood of Ulmus L. in Poland. Polish Journal of Entomology 76(2): 101-105.

Č́̇̌̌EK L., Schlaghamerský J., BoŘuckÝ J., Hauck D., Helešic J. 2009. Range expansion of an endangered beetle: Alpine Longhorn Rosalia alpina (Coleoptera: Cerambycidae) spreads to the lowlands of Central Europe. Entomologica Fennica 20(3): 200-206.

Drag L., Čížé L., Pokluda P., Hauck D., Honcư M., RoztočIl O. 2012. Rosalia Longicorn and its occurrence in the Czech Republic. Živa 5: 247-250. [In Czech]

Drag L., Hauck D., Pokluda P., Zimmermann K., Č́žžeK L. 2011. Demography and dispersal ability of a threatened saproxylic beetle: a mark-recapture study of the Rosalia Longicorn (Rosalia 
alpina). PLoS ONE 6(6): e21345.

Duelli P., Wermelinger B. 2005. Der Alpenbock (Rosalia alpina). Ein seltener Bockkäfer als Flaggschiff-Art. Merkblatt für die Praxis (Eidgenössische Forschungsanstalt WSL) 39: 1-8.

EHNSTRÖM B. 2007. Rosalia alpina alpbock. [in:] B. EHNSTRÖM, M. HOLMER. The Encyclopedia of the Swedish Flora and Fauna. Longhorn beetles. Coleoptera: Cerambycidae. Artdatabanken, SLU, Uppsala: 196-197. [in Swedish]

GEPP J. 2002. Rosalia alpina L. Österreichs Insect des Jahres 2001. Entomologica Austriaca 5: 3-4.

Gutowski J.M., PrzewoźNy M. 2013. Natura 2000 as a tool to conserve beetles (Coleoptera) in Poland. Wiadomości Entomologiczne 32(Supl.): 5-40. [in Polish]

IUCN (InTERnAtional UNION FOR CONSERvation OF NATURe). 2014. World Conservation Monitoring Centre 1996. Rosalia alpina. The IUCN Red List of Threatened Species. Version 2014.3. http://www.iucnredlist.org. Downloaded on 18 November 2014.

JENDEK B., JENDEK E. 2006. An analysis of the beetle conservation in Slovakia based on the longicorn beetles (Coleoptera, Cerambycidae) as a model group. Folia faunistica Slovaca 11(4): 15-28. [in Slovak]

KONDRACKI J. 2000. Regional geography of Poland. Wydawnictwo Naukowe PWN, Warszawa. [in Polish]

Lachat T., Ecker K., Duelli P., Wermelinger B. 2013. Population trends of Rosalia alpina (L.) in Switzerland: a lasting turnaround? Journal of Insect Conservation 17(4): 653-662.

Michalcewicz J., BodziarczyK J. 2008. Rosalia alpina (Linnaeus, 1758) (Coleoptera, Cerambycidae) in the Pieniny National Park. Pieniny - Przyroda i Człowiek 10: 67-73. [in Polish]

Michalcewicz J., BodZiARCZYK J. 2001. The occurrence and conservation of Rosalia alpina (L.) (Coleoptera, Cerambycidae) in the Pieniny National Park. Chrońmy Przyrodę Ojczystą 57(5): 88-93. [in Polish]

Michalcewicz J., BodziarczyK J., Ciach M. 2013. Development of the Rosalia longicorn Rosalia alpina (L.) (Coleoptera: Cerambycidae) in the sycamore maple Acer pseudoplatanus L. - the first report from Poland. Polish Journal of Entomology 82(1): 19-24.

Michalcewicz J., Ciach M. 2012a. Biometry of adult Rosalia longicorn Rosalia alpina (L.) (Coleoptera: Cerambycidae) from the Polish Carpathians: a preliminary study. Polish Journal of Entomology 81(4): 311-320.

Michalcewicz J., Ciach M. 2012b. Protection of Rosalia longicorn Rosalia alpina (Coleoptera: Cerambycidae) in Poland - the current problems and solutions. Chrońmy Przyrodę Ojczystą 68(5): 347-357. [in Polish]

Michalcewicz J., Ciach M. 2012c. Rosalia longicorn Rosalia alpina (L.) (Coleoptera: Cerambycidae) uses roadside European ash trees Fraxinus excelsior L. - an unexpected habitat of an endangered species. Polish Journal of Entomology 81(1): 49-56.

Michalcewicz J., Ciach M., BodziarczYK J. 2011a. The unknown natural habitat of Rosalia alpina (L.) (Coleoptera: Cerambycidae) and its trophic association with the mountain elm Ulmus glabra in Poland - a change of habitat and host plant. Polish Journal of Entomology 80(1): 23-31. 
Michalcewicz J., Ilek A., Szafarska J., Wach A. 2011b. Rosalia longicorn Rosalia alpina (L.) (Coleoptera: Cerambycidae) in the Forest Division of Łosie (SE Poland) - distribution, certain aspects of ecology, threats and species conservation. Acta Agraria et Silvestria, Series Silvestris 49: 25-34. [in Polish]

MichalCEWicz J., ŁusZCZAK M. 2014. New records of Rosalia alpina (LinnAEus, 1758) (Coleoptera: Cerambycidae) occurrence in the Beskid Sądecki Mts. Wiadomości Entomologiczne 33(1): 7374. [in Polish]

QGIS (Quantum GIS Development Team). 2014. Quantum GIS Geographic Information System. Open Source Geospatial Foundation Project. http://qgis.osgeo.org/

Russo D., Cistrone L., Garonna A. 2011. Habitat selection by the highly endangered long-horned beetle Rosalia alpina in Southern Europe: a multiple spatial scale assessment. Journal of Insect Conservation 15(5): 685-693.

SAMA G. 2002. Atlas of the Cerambycidae of Europe and the Mediterranean Area. Volume 1: Northern, Western, Central and Eastern Europe. British Isles and Continental Europe from France (excl. Corsica) to Scandinavia and Urals. Nakladatelství Kabourek, Zlín.

Shapovalov A.M. 2012. Longicorn-beetles (Coleoptera, Cerambycidae) of Orenburg Region: fauna, distribution, bionomy. Archives of Orenburg Branch of Russian Entomological Society, volume 3. Orenburg Branch of Russian Entomological Society, Orenburg. [in Russian]

SLÁma M.E.F. 1998. Longhorn beetles - Cerambycidae of the Czech Republic and the Slovak Republic (Beetles - Coleoptera). Milan SLÁMA, Krhanice. [in Czech]

ŠOPSR (ŠTÁtna OChrana PRíRody SLOVENSKeJ RePubliky). 2014. Reporting under Article 17 of the Habitats Directive for the period 2004-2006. Rosalia alpina - occurrence. Interntet: http://www.sopsr.sk/natura/images/mapy_dab/vyskyt/pic-distribution-spec-rosalia-alpina.jpg. Downloaded on 31 December 2014

STARZYK J.R. 1992. Rosalia alpina (LiNNÉ, 1758), Rosalia Longicorn. [In:] Z. GŁOWACIŃSKI (ed.). Polish Red Data Book of Animals. PWRiL, Warszawa: 295-296. [In Polish]

STARZYK J.R. 2004. Rosalia alpina (LinNAEus, 1758), Rosalia Longicorn. [In:] Z. GŁowACIŃSKI, J. NOWACKI (eds). Polish Red Data Book of Animals. Invertebrates. IOP PAN Kraków, AR Poznań: 148-149. [in Polish]

StePhens P.A., Sutherland W.J., Freckleton R.P. 1999. What is the Allee effect? Oikos 87(1): $185-190$.

ŠvÁCHA P., DANILEvSKy M.L. 1988. Cerambycoid larvae of Europe and Soviet Union (Coleoptera, Cerambycoidea). Part II. Acta Universitatis Carolinae, Seria Biologica 31: 121-284.

Zygarowicz J. 2003. A new station of Rosalia alpina in the Beskid Niski Mts. Chrońmy Przyrodę Ojczystą 59(5): 136-137. [in Polish]

Received: 31 December 2014

Accepted: 5 January 2015 